\title{
Antiplasmodial activity of some phenolic compounds from Cameroonians Allanblackia
}

\author{
Anatole Guy Blaise Azebaze ${ }^{1}$, Jean Emmanuel Mbosso Teinkela ${ }^{1,2}$, Edwige Laure Nguemfo², \\ Alexis Valentin ${ }^{3}$, Alain Bertrand Dongmo ${ }^{4}$, Juliette Cathérine Vardamides ${ }^{1}$
}

1. Department of Chemistry, Faculty of Science, University of Douala, P.O. Box. 24157, Douala, Cameroon

2. Department of Biological Sciences, Faculty of Medicine and Pharmaceutical Sciences, University of Douala, P.O. Box. 2701 Douala, Cameroon

3. Pharmacochimie des Substances Naturelles et Pharmacophores Redox, UMR 152 IRD-UPS, Université Paul Sabatier, Faculté des Sciences Pharmaceutiques, 35, Chemin des Maraîchers 31062 Toulouse Cedex 4, France

4. Department of Animal Biology and Physiology, Faculty of Science, University of Douala, P.O. Box. 24157, Douala, Cameroon

\begin{abstract}
Background: Plasmodium falciparum, one of the causative agents of malaria, has high adaptability through mutation and is resistant to many types of anti-malarial drugs. This study presents an in vitro assessment of the antiplasmodial activity of some phenolic compounds isolated from plants of the genus Allanblackia.

Methods: Tests were performed on well plates filled with a fixed parasitized erythrocytes volume. Compounds to be tested were then added in wells. After incubation, tritiated hypoxanthine is added and the plates were returned to the incubator. After thawing, the nucleic acids are collected. Inhibitory Concentration 50 (IC50) was determined by linear interpolation.

Results: From Allanblackia floribunda, have been isolated and characterized 1,7-dihydroxyxanthone 1, macluraxanthone 4, morelloflavone 9, Volkensiflavone 10 and morelloflavone 7-O-glucoside 11; from Allanblackia monticola, $\alpha$-mangosine 2 , rubraxanthone 3, allaxanthone C 5, norcowanine 6 , tovophiline A 7, allaxanthone B 8 and from Allanblackia gabonensis, 1,7-dihydroxyxanthone 1. Six of them were evaluated for their antimalarial properties. The most active compound, macluraxanthone, presented a very interesting activity, with an IC50 of 0.36 and $0.27 \mu \mathrm{g} / \mathrm{mL}$ with the F32 and FcM29 strains respectively.

Conclusion: This work confirms that species of Allanblackia genus are medicinally important plants containing many biologically active compounds that can be used effectively as antiplasmodial.

Key words: Guttiferaceae, Allanblackia, Phenolic compounds, Antiplasmodial activity

DOI: http://dx.doi.org/10.4314/ahs.v15i3.18

Cite as: Azrebaze AGB, Teinkela JEM, Nguemfo EL, Valentin A, Dongmo AB, Vardamides JC. Antiplasmodial activity of some phenolic compounds from Cameroonians Allanblackia. Afri Health Sci. 2015;15(3):835-40. doi: http:// dx.doi.org/10.4314/abs.v15i3.18
\end{abstract}

\section{Introduction}

Malaria remains one of the major pandemics and is a main public health problem especially in Africa ${ }^{1}$. Ma-

\author{
Corresponding authors: \\ Anatole Guy Blaise Azebaze, \\ Department of Chemistry, \\ Faculty of Science, University of Douala, \\ P.O.Box. 24157, Douala, Cameroon \\ Phone: +237699637624 \\ E-mail: azebaze@yahoo.com; \\ Jean Emmanuel Mbosso Teinkela, \\ Department of Biological Sciences, \\ Faculty of Medicine and Pharmaceutical Sciences, \\ University of Douala, \\ P.O. Box. 2701 Douala, Cameroon \\ Phone: +237675003069 \\ E-mail: embosso@yahoo.fr
}

laria is found in tropical and sub-tropical regions of the southern hemisphere. More than two billions people are at risk of contracting this disease worldwide. A microscopic parasite called Plasmodium falciparum is responsible for the most dangerous form of malaria. This parasite is transmitted by the female mosquito species belonging to the genus Anopheles².

Currently, despite the existing therapeutic arsenal, few drugs are available in the market and are not always accessible to the affected population. Additionally, the increased parasite's resistance to current treatments reinforces the urgent need to search for new antimalarial drugs. Because of the high cost of the prescribed drugs and the various activities displayed by medicinal plants against many diseases, $80 \%$ of the world population relies on medicinal plants for their basic and first healthcare. Two current so-called antimalarial drugs have been derived from medicinal plants traditionally used in 
their countries of origin against fevers and malaria. This includes the bark of a tree native to the slopes of the Andean Cordillera (Cinchona calisaya and other species of Cinchona) and a native Chinese herb Artemisia annua ${ }^{3}$. These findings encourage the search for new antimalarial drugs in plant biodiversity. In Cameroon, a large number of plant species have been identified as antimalarial medicinal plants. Pure natural products compounds have been isolated from some of these plants and their antimalarial activities were comparable to or more active than chloroquine on sensitive and resistant strains of $P$. falciparum ${ }^{4}$. Plasmodium falciparum, one of the causative agents of malaria, has high adaptability through mutation and is resistant to many types of anti-malarial drugs. This resistance is a serious setback to antimalarial programs since it precludes the use of cheap and previously effective drugs like chloroquine. New families of active compounds are needed, especially from natural sources in order to decrease the risk of resistance. An alternative solution in many endemic countries is the use of traditional medicinal plants since many of the available antimalarial drugs are from plants sources, and the potential of plants to produce new antiprotozoal agents are considerable.

The phytochemical and pharmacology studies of plants of the genus Allanblackia revealed the presence of biologically active secondary metabolites belonging to benzophenones, xanthones, triterpenes, phytosterols and biflavonoids $^{5-9}$. A floribunda was studied for antioxidant, antitumor and antimicrobial activities ${ }^{10}$, ejaculatory activities ${ }^{11}$, antioxidative properties and hypolipidemic effects $^{12}$, free radical scavenging activities ${ }^{13} ; A$ monticola for leishmanicidal and cholinesterase activities ${ }^{14}$, anti-inflammatory and anti-nociceptive activities ${ }^{15}$, anti-oxidative and anti-inflammatory activities ${ }^{16}$, apoptotic and antiproliferative activities ${ }^{9}$ and for antiplasmodial activity $^{17,18}$; A. gabonensis for antiparasitic and antimicrobia ${ }^{18}$, hepatho-nephroprotective and antioxidant activities ${ }^{19}$, analgesic and anti-inflammatory activities ${ }^{20}$.

In the present study, we report on the antiplasmodial activity of isolated phenolic compounds which were not evaluated before as well as the crude extracts from some cameroonian plants of the genus Allanblackia: $A$. floribunda, A. monticola and A. gabonensis.

\section{Materials and methods}

\section{Plant materials}

Allanblackia floribunda, Allanblackia gabonensis and Allanblackia monticola plants belonging to the family of Guttiferaceae were collected respectively on top of Mount
Kala in the Central Region Cameroon for the first two species and Bangangté area of Western Cameroon to the latter species. They were then identified by Dr. Zapfack from the Botany Department at the University of Yaounde I. Voucher specimens were deposited at the National Herbarium of Cameroon.

\section{Extraction and isolation}

Plants were then cut, air-dried and powdered. The powders obtained were then macerated with $\mathrm{CH}_{2} \mathrm{Cl}_{2} /$ $\mathrm{MeOH}(1 / 1)$ at room temperature for $48 \mathrm{~h}$ followed by pure methanol for 4 hours. After evaporation under reduced pressure, the crude extracts were obtained ${ }^{8,10,16}$. The various crude extracts were submitted to fractionation using hexane-ethyl acetate of increasing polarity as eluent. Fractions of $300 \mathrm{~mL}$ were collected and pooled on the basis of their thin layer chromatography (TLC) profiles. Further purification through successive column chromatography yielded several pure compounds belonging to many classes of compounds.

\section{Identification of compounds}

The isolated compounds were then characterized using various spectroscopic and spectrometric techniques such as 1D- and 2D-NMR and MS. Melting points were determined using a Kofler bench and are uncorrected. The mass spectra were recorded on a API Q-STAR PULSAR spectrometer. The ${ }^{1} \mathrm{H}$ - and ${ }^{13} \mathrm{C}-\mathrm{NMR}$ spectra were recorded on a Bruker 300 and $75 \mathrm{MHz}$ spectrometer respectively with TMS as internal standard. Coupling constants are expressed in Hertz. NOESY, HMBC, HSQC and Jmod experiments were performed with conventional pulse sequences and on a $400 \mathrm{MHz}$ Brucker spectrometer. Column chromatography (CC) and TLC were carried out on silica gel $60 \mathrm{H}$ Merk, 70230, 200-300 mesh; GGo, GF254 aluminum plates 20 x $20 \mathrm{~cm}$ Merck and Analtech; respectively. Spots were visualized by UV lamp ( $254 \mathrm{~nm}$ and $365 \mathrm{~nm}$ ) or by spraying with $50 \% \mathrm{H}_{2} \mathrm{SO}_{4} / \mathrm{H}_{2} \mathrm{O}$ solution, or using iodine. The in vitro antimalarial activity was performed on two reference strains of Plasmodium falciparum: the $\mathrm{F}_{32}$ strain from Tanzania, chloroquine-sensitive and native ofCameroon $\mathrm{FcM}_{29}$ strain resistant to chloroquine ${ }^{21}$. The tests were performed using the radio-isotope technique based on the method previously described by Desjardins $^{22}$ and modified by Benoit ${ }^{23}$.

\section{Assays of bio-activity}

Tests were performed on 96 well plates filled with a fixed parasitized erythrocytes (parasitemia of $1.0 \%$ and $1.5 \%$ hematocrit) volume. Fractions to be tested (at 
different concentrations) were then added in triplicate wells. After $24 \mathrm{~h}$ incubation at $37^{\circ} \mathrm{C}, 0.25 \mu \mathrm{Ci}$ of the tritiated hypoxanthine is added in each well (Perkin Elmer $1 \mu \mathrm{Ci} / \mathrm{mL}$, France) and the plates were returned to the incubator for $24 \mathrm{~h}$. At the end of the cycle, the plates are frozen at $-20^{\circ} \mathrm{C}$ to cause hemolysis of erythrocytes. After thawing (4th day), the nucleic acids are collected onto filters using an automated cell collector (Perkin Elmer, France). The radioactivity on the filter (dried in a microwave and wrapped in plastic to which are added $4 \mathrm{~mL}$ of liquid scintillation (Betaplate Scint, Perkin Elmer) is then measured by a $\beta$ counter (Microbeta Trilux, Perkin Elmer). Inhibitory Concentration 50 (IC50) (sample concentration which inhibits $50 \%$ of the para- site growth) is determined by linear interpolation, with the ratio of the percentage of parasitemia on the logarithm of the concentrations of samples. The radioactivity reading determines (by linear regression analysis) the Inhibitory Concentration 50.

\section{Results}

After the characterization of the isolated compounds, we identified 05 pure compounds from $A$. floribunda: 1,7-dihydroxyxanthone, macluraxanthone, morelloflavone, volkensiflavone and morelloflavone 7-O-glucoside $^{10,24}, 06$ from $A$. monticola: $\alpha$-mangosine, rubraxanthone, allaxanthone, norcowanine, tovophiline A, allaxanthone $\mathrm{B} 7,{ }^{16}$ and 01 from $A$. gabonensis, 1,7-dihydroxyxanthone ${ }^{8}$. The structures are showed in Table 1.

Table 1. Chemical structure of isolated compounds from Allanblackia

\begin{tabular}{|c|c|c|c|}
\hline Name & Structure & Source & References \\
\hline 1,7-dihydroxyxanthone & & $\begin{array}{l}\text { A. gabonensis, } \\
\text { A. floribunda }\end{array}$ & {$[8,10,16]$} \\
\hline$\alpha$-mangosine & & A. monticola & {$[8,16]$} \\
\hline rubraxanthone & & A. monticola & {$[8,16]$} \\
\hline macluraxanthone & & A. floribunda & {$[10,21]$} \\
\hline allaxanthone $\mathrm{C}$ & & A. monticola & {$[8,16]$} \\
\hline norcowanine & & A. monticola & {$[8,16]$} \\
\hline tovophiline A & & A. monticola & {$[8,16]$} \\
\hline allaxanthone B & & A. monticola & {$[8,16]$} \\
\hline morelloflavone & & A. floribunda & {$[10,24]$} \\
\hline volkensiflavone & & A. floribunda & {$[10,24]$} \\
\hline $\begin{array}{l}\text { morelloflavone } \\
\text { glucoside }\end{array}$ & & A. floribunda & {$[10,24]$} \\
\hline
\end{tabular}


It is clear from this table that the phenolic compounds contained in the plants of the genus Allanblackia are mainly xanthones and biflavonoids.

Xanthones: The xanthones isolated from $A$. floribunda, are both prenylated and non-prenylated, while those of A. monticola have in their structure at least one prenyl or geranyl group. Xanthones from $A$. monticola have a $\mathrm{B}$ ring dioxygenated in position 6,7 and prenyles or geranyles groups are in positions $2,4,5$ or 8 . The isolated compound from $A$. gabonensis is a oxygenated xanthone.

Biflavonoids: These groups of compounds have mainly been isolated from $A$. floribunda and their two constitutive units are different (flavanone-flavone type).

The linear regression allowed determining the IC50 of the tested compounds (Table 2).

Table 2. Evaluation of in vitro antiplasmodial activity of the different compounds tested on $P$. falciparum $\mathrm{F}_{32}$ and $\mathrm{FcM}_{29}$ strains in comparison with chloroquine as reference $\left(\mathrm{IC}_{50}\right.$ in $\left.\mu \mathrm{g} / \mathrm{mL}\right)$

\begin{tabular}{lc|c|c|c|c}
\hline \multirow{2}{*}{ Compounds } & \multicolumn{1}{c}{$\mathrm{F}_{32} / 24 \mathrm{~h}$} & $\mathrm{~F}_{32} / 72 \mathrm{~h}$ & $\mathrm{FcM}_{29} / 24 \mathrm{~h}$ & $\mathrm{FcM}_{29} / 72 \mathrm{H}$ \\
\cline { 2 - 5 } & \multicolumn{1}{c}{$\mathrm{IC}_{50}$} & $\mathrm{IC}_{50}$ & $\mathrm{IC}_{50}$ & $\mathrm{IC}_{50}$ \\
\hline 1,7-dihydroxy xanthone1 & $16.05+/-9.02$ & $19.87+/-19.15$ & $17.93+/-5.40$ & $15.34+/-4.23$ \\
macluraxanthone & $\mathbf{4}$ & $0.46+/-0.12$ & $0.36+/-0.06$ & $0.33+/-0.08$ & $0.27+/-0.01$ \\
allaxanthone B & $\mathbf{8}$ & $3.70+/-1.05$ & $3.09+/-0.13$ & $3.93+/-0.40$ & $3.43+/-0.57$ \\
morreloflavone & $\mathbf{9}$ & $11.77+/-9.55$ & $3.36+/-2.00$ & $12.59+/-12.03$ & $4.80+/-2.21$ \\
volkensiflavone & $\mathbf{1 0}$ & $0.99+/-0.62$ & $1.18+/-1.25$ & $0.93+/-0.20$ & $0.95+/-0.27$ \\
morreloflavone 7-O- & & & & & \\
glucoside & $\mathbf{1 1}$ & & & & \\
& & $11.45+/-14.51$ & $8.38+/-10.87$ & $28.92+/-7.45$ & $23.82+/-7.58$ \\
chloroquine & & 0.036 & 0.036 & 0.57 & 0.57 \\
EAF & $5.38+/-0.83$ & $5.43+/-1.31$ & $4.92+/-1.43$ & $4.48+/-1.47$ \\
EAG & $35.38+/-2.87$ & $32.01+/-1.21$ & $25.17+/-2.87$ & $24.30+/-4.04$ \\
EAM & $3.27+/-0.25$ & $3.33+/-0.17$ & $3.08+/-0.08$ & $2.13+/-1.07$ \\
\hline
\end{tabular}

EAF: Crude extract of the bark of $A$. floribunda, EAM: Crude extract from the bark of $A$. monticola, EAG: Crude extract fromthe bark of $A$. gabonensis.

After $24 \mathrm{~h}$ of contact with the parasite, volkensiflavone (IC50: $0.99 \mu \mathrm{g} / \mathrm{mL}$ ) and macluraxanthone (IC50: 0.46 $\mu \mathrm{g} / \mathrm{mL})$ displayed the best activity on the $\mathrm{F}_{32}$ strain while chloroquine (IC50: $0.036 \mu \mathrm{g} / \mathrm{mL}$ ) was used as reference. With FcM29 strain, volkensiflavone (IC50: 0.93 $\mu \mathrm{g} / \mathrm{mL}$ ) and macluraxanthone (IC50: $0.33 \mu \mathrm{g} / \mathrm{mL}$ ) remained the most active compounds, but the macluraxanthone was more active than the reference (chloroquine: IC50: $0.57 \mu \mathrm{g} / \mathrm{mL}$ ). After $72 \mathrm{~h}$ of contact, macluraxanthone (IC50: $0.36 \mu \mathrm{g} / \mathrm{mL}$ ) exhibited the high activity on the $\mathrm{F}_{32}$ strain and with $\mathrm{FcM}_{29}$ strain, it was most active (IC50: $0.27 \mu \mathrm{g} / \mathrm{mL}$ ). Additionally, several other compounds also showed good activities: volkensiflavone (IC50: $0.95 \mu \mathrm{g} / \mathrm{mL}$ ) and $\alpha$-mangosine 
(IC50: $0.33 \mu \mathrm{g} / \mathrm{mL}$ ). For the most active compounds (macluraxanthone), we noted that when it was allowed to go from 24 to $72 \mathrm{~h}$ of contact with parasite, there was increased activity of $0.1 \mu \mathrm{g} / \mathrm{mL}$ with the $\mathrm{F}_{32}$ strain and $0.06 \mu \mathrm{g} / \mathrm{mL}$ with FcM29 strain. Similarly, for $\alpha$-mangosine, we got an increase in activity of $1.39 \mu \mathrm{g} / \mathrm{mL}$ with $\mathrm{FcM}_{29}$ layer. In contrast, for volkensiflavone there was a decrease in activity of $0.19 \mu \mathrm{g} / \mathrm{mL}$ with the $\mathrm{F}_{32}$ strain and $0.02 \mu \mathrm{g} / \mathrm{mL}$ with $\mathrm{FcM}_{29}$ strain when going from 24 to $72 \mathrm{~h}$ of contact with parasite.

\section{Discussion}

From all tested compounds, macluraxanthone is the most active compound on two strains of Plasmodium with a mean IC50 of 0.36 and $0.27 \mu \mathrm{g} / \mathrm{mL}$ for the $F_{32}$ and $\mathrm{FcM}_{29}$ strains respectively. Five of those prenylated xanthones ( $\alpha$-mangosine, tovophiline $A$, allaxanthone $\mathrm{C}$, rubraxanthone, norcowanine) isolated form $A$. monticola previously tested for antiplasmodial properties had displayed after $24 \mathrm{~h}$ of contact with the parasite a significant antiplasmodial activity (IC50: $1.96-3,16 \mu \mathrm{g}$ / $\mathrm{mL}$ ) on the $\mathrm{F}_{32}$ strain and (IC50: $1.72-3.22 \mu \mathrm{g} / \mathrm{mL}$ ) on $\mathrm{FcM}_{29}{ }^{17,18}$. This activity is less interesting than that of macluraxanthone (IC50: 0.46 and $0.33 \mu \mathrm{g} / \mathrm{mL}$ respectively with $\mathrm{F}_{32}$ and $\mathrm{FcM}_{29}$ ). We also noted that its chemical structure contains two isoprene chain groups.1,7 dihydroxanthone (without isoprenyl group) showed very low activity $(16,05 \mu \mathrm{g} / \mathrm{mL})$.

It can then be suggested that the antiplasmodial activities of these compounds could be improved by the presence of isoprenyl groups on their structures. For comparison, four xanthones and three of their analogues have been isolated from Cratoxylum maingayi and Cratoxylum cochinchinense (Clusiaceae), respectively, and these compounds showed antiplasmodial activity against $P$. falciparum at concentrations of 11.0 to 1.9 $\mu \mathrm{M}^{25}$, less active than macluraxanthone $(0.6 \mu \mathrm{M})$. As for biflavonoids, those flavanone-flavone types are the most active. Volkensiflavone exhibited antiplasmodial activity with mean IC50 of $1.5 \mu \mathrm{M}$, which is a significant value compared to those of other biflavonoids. For example, four biflavonoids were isolated from Ormocarpum kirkii and showed antiplasmodial activity toward $P$. falciparum strain $\mathrm{K} 1$; isochamaejasmin was the most active among the four with an IC50 of $7.3 \mu \mathrm{M}^{26}$. For the three biflavonoides tested, we realize that the presence of the hydroxyl group in position 3' in the morelloflavone and morelloflavone 7-O-glucoside (IC50: 11.77 and $11.45 \mu \mathrm{g} / \mathrm{mL}$ respectively) causes a sharp drop in activity compared to that of the volkensiflavone (IC50: $0.99 \mu \mathrm{g} / \mathrm{mL}$ ) with the $\mathrm{F}_{32}$ strain after $24 \mathrm{~h}$ contact with the parasite, but also in general way. Moreover, it was reported that the activity exhibited by the crude extract of A. monticola was ascribed to the synergy of its polyisoprenylated xanthones.

\section{Conclusion}

This work confirms that species of Allanblackia genus are medicinally important plants containing many biologically active compounds that can be used effectively as antiplasmodial. The antiplasmodial activity of these isolated phenolic compounds were particularly high and more so with isoprenylated ones. This study can validate at least in part the uses of species of Allanblack$i a$ for the treatment of febrile aches. Further studies are however required to establish the role played by the isoprenylated groups in antiplasmodial study. The isolated compounds tested in this investigation can also be suggested as lead compounds for future development of economic antimalarial drugs.

\section{Competing interests}

The authors declare that they have no competing interest.

\section{References}

1. OMS. Geneva: World Health Organization. WHO/ HTM/GMP/2008.1, 2008.

2. OMS. Geneva, OMS/UNICEF/RBM, World malaria report, 2005.

3. Pradines B, Dormoi J, Briolant S, Bogreau H and Rogier C. La résistance aux antipaludiques. Revue Française des Laboratoires 2010; 422: 51-62.

4. Tane P, Wabo H, Tchimene M, Okunji C, Iwu M, Schuster B and Connolly J. Lead antiplasmodial substances from some Cameroonian medicinal plants. $A b$ stract/Acta tropica 2005; 96S(2005): S1-S506.

5. Fuller WR, Blunt WJ, Boswell LJC and Boyd RM. Guttiferone F. The first prenylated benzophenone from Allanblackia stublmannii. Journal of Natural Product 1999; 62(1): 130-132.

6. Ngouela S, Zelefack F, Lenta NB, Ngouamegne TE, Tchamo ND, Tsamo E and Connolly DJ. Xanthones and other constituents of Allanblackia monticola (Guttiferae). Natural Product Research 2005; 19(7): 685-688.

7. Azebaze AGB, Meyer M, Bodo B and Nkengfack EA. Allanxanthone B, a polyisoprenylated xanthone from the stem bark of Allanblackia monticola Staner L.C. Phytochemistry 2004; 65(18): 2561-2564. 
8. Azebaze AGB, Ouahouo MWB, Valentin A, Kuete V, Nguemfo EL, Acebey L, Beng VP, Nkengfack AE and Meyer M. Antimicrobial and antileishmanial xanthones from the stem bark of Allanblackia gabonensis (Guttiferae). Natural Product Research 2008; 22(4): 333-341.

9. Azebaze AGB, Menasria F, Meyer M, Noumi LGN, Nguemfo EL, Nkengfack AE and Kolb JP. Xanthones from the seeds of Allanblackia monticola and their apoptotic and antiproliferative activities. Planta Medica 2009; 75(3): 243-248.

10. Kuete V, Azebaze AGB, Mbaveng AT, Nguemfo E.L, Tshikalange ET, Chalard P, and Nkengfack AE. Antioxidant, antitumor and antimicrobial activities of the crude extract and compounds of the root bark of Allanblackia floribunda. Pharmaceutical Biology 2011; 49(1): 57-65.

11. Kada SA, Miegueu P, Bilanda DC, Faleu NNM, Watcho P, Djomeni PD and Kamtchouing P. Ejaculatory activities of Allanblackia floribunda stem bark in spinal male rats. Pharmacentical Biology 2013; 51(8): 1014-1020. 12. Boudjeko T, Ngomoyogoli KEJ, Woguia LA and Yanou NN. Partial characterization, antioxidative properties and hypolipidemic effects of oilseed cake of $A l$ lanblackia floribunda and Jatropha curcas. BMC Complementary and Alternative Medicine 2013; 13: 352.

13. Ayoola AG, Ipav SS, Sofidiya OM, Adepoju-Bello $\mathrm{AA}$, Coker ABH and Odugbemi OT. Phytochemical Screening and Free Radical Scavenging Activities of the Fruits and Leaves of Allanblackia floribunda Oliv (Guttiferae). International Journal of Health Research 2008; 1(2): 87-93.

14. Lenta NB, Vonthron-Sénécheau C, Weniger B, Devkota PK, Ngoupayo J, Kaiser M, Naz Q, Choudhary IM, Tsamo E and Sewald N. Leishmanicidal and cholinesterase inhibiting activities of phenolic compounds from Allanblackia monticola and Symphonia globulifera. Molecules 2007; 12(8): 1548 PubMed -1557.

15. Nguemfo EL, Dimo T, Azebaze AGB, Asongalem AE, Alaoui K, Dongmo BA, Cherrah Y and Kamtchouing P. Anti-inflammatory and anti-nociceptive activities of the stem bark extracts from Allanblackia monticola Staner L.C. (Guttiferae). Journal of Ethnopharmacology 2007; 114(3): 417-424.

16. Nguemfo EL, Dimo T, Dongmo AB, Azebaze AGB, Alaoui K, Asongalem AE, Cherrah YP and Kamtchouing P. Anti-oxidative and anti-inflammatory activities of some isolated constituents from the stem bark of
Allanblackia monticola Staner L.C (Guttiferae). Inflammopharmacology 2009; 17(1): 37-41.

17. Azebaze AGB, Meyer M, Valentin A, Nguemfo EL, Fomum ZT, Nkengfack AE. Prenylated xanthone derivatives with antiplasmodial activity from Allanblackia monticola Staner L.C. Chemical Pharmaceutical Bulletin 2006; 54(1): 111-113.

18. Azebaze AGB, Dongmo AB, Meyer M, Ouahouo BMW, Valentin A, Nguemfo EL, Nkengfack AE, Vierling W. Antimalarial and vasorelaxant constituents of the leaves of Allanblackia monticola (Guttiferae). Annals of Tropical Medicine and Parasitology 2007; 101(1): 23-30.

19. Vouffo YE, Donfack MF, Temdie JR, Ngueguim TF, Donfack HJ, Dzeufiet DD, Dongmo BA and Dimo T. Hepatho-nephroprotective and antioxidant effect of stem bark of Allanblackia gabonensis aqueous extract against acetaminophen-induced liver and kidney disorders in rats. Journal of Experimental and Integrative Medicine 2012; 2(4): 337-344.

20. Ymele EV, Dongmo AB and Dimo T. Analgesic and anti-inflammatory effect of aqueous extract of the stem bark of Allanblackia gabonensis (Guttiferae). Inflammopharmacology 2013; 21(1): 21-30.

21. Trager $W$ and Jensen JB. Human malaria parasites in continuous culture. Science 1976; 193(4254): 673-675. 22. Desjardins RE, Canfield CJ, Haynes JD and Chulay JD. Quantitative assessment of antimalarial activity in vitro by a semiautomated microdilution technique. $A n$ timicrobial Agents and Chemotherapy 1979; 16(6): 710-718.

23. Benoit F, Valentin A, Pélissier Y, Diafouka F, Marion C, Dakuyo Z, Mallié M, Bastide JM. Antimalarial activity in vitro of Cochlospermum tinctorium tubercle extracts. Transactions of the Royal Society of Tropical Medicine and Hygiene 1995; 89(2): 217-218.

24. Nkengfack AE, Azebaze AGB, Vardamides JC, Fomum ZT and Van Heerden FR. A prenylated xanthone from Allanblackia floribunda. Phytochemistry 2002; 60(4): 381-384.

25. Laphookhieo S, Maneerat W and Koysomboon S. Antimalarial and cytotoxic phenolic compounds from Cratoxylum maingayi and Cratoxylum cocbinchinense. Molecules 2009; 14(4): 1389-1395.

26. Dhooghe L, Maregesi S, Mincheva I, Ferreira D, Marais JPJ, Lemière F, Matheeussen A, Cos P, Maes L, Vlietinck A, Apers S and Pieters L. Antiplasmodial activity of (I-3,II-3)-biflavonoids and other constituents from Ormocarpum kirkii. Phytochemistry 2010; 71(7): 785791. 